\title{
A Compendium of the Mouse Mammary Tumor Biologist: From the Initial Observations in the House Mouse to the Development of Genetically Engineered Mice
}

\author{
Robert D. Cardiff ${ }^{1}$ and Nicholas Kenney ${ }^{2}$ \\ ${ }^{1}$ Center for Comparative Medicine, University of California, Davis, Davis, California 95616 \\ ${ }^{2}$ Department of Biological Sciences, Hampton University, Hampton, Virginia 23668 \\ Correspondence: rdcardiff@ucdavis.edu
}

For over a century, mouse mammary tumor biology and the associated mouse mammary tumor virus (MMTV) have served as the foundation for experimental cancer research, in general, and, in particular, experimental breast cancer research. Spontaneous mouse mammary tumors were the basis for studies of the natural history of neoplasia, oncogenic viruses, host responses, endocrinology and neoplastic progression. However, lacking formal proof of a human mammary tumor virus, the preeminence of the mouse model faded in the 1980s. Since the late 1980s, genetically engineered mice (GEM) have proven extremely useful for studying breast cancer and have become the animal model for human breast cancer. Hundreds of mouse models of human breast cancer have been developed since the first demonstration in 1984. The GEM have attracted a new generation of molecular and cellular biologists eager to apply their skill sets to these surrogates of the human disease. Newcomers often enter the field without an appreciation of the origins of mouse mammary tumor biology and the basis for many of the prevailing concepts. Our purpose in writing this compendium is to extend an "olive branch" while simultaneously deepen the knowledge of the novice mouse mammary tumor biologist as they journey into a field rich in pathology and genetics spanning several centuries.

$T^{\mathrm{h}}$ he first mice genetically engineered for $M y c$ were through the use of the MMTV-LTR (Stewart et al. 1984). These mice were later followed by the ras and $c$-neu transgenic mice Tg (ras) and $\operatorname{Tg}(n e u)$ transgenics (Sinn et al. 1987; Muller et al. 1988; Guy et al. 1992). Thus started the transgenic revolution using a long list of promoter systems and genes. Along with this came a large number of molecular and cellular biologists whose training is outside mouse mammary biology and scientific perspective has enriched and reinvigorated mouse mammary tumor biology. The very first lesson of GEM is the realization that when scientists recapitulated what MMTV had performed in nature, that is, place the Int genes behind the

Editors: Mina J. Bissell, Kornelia Polyak, and Jeffrey Rosen

Additional Perspectives on The Mammary Gland as an Experimental Model available at www.cshperspectives.org

Copyright (C) 2011 Cold Spring Harbor Laboratory Press; all rights reserved; doi: 10.1101/cshperspect.a003111

Cite this article as Cold Spring Harb Perspect Biol 2011;3:a003111 
MMTV LTR promoter, mice usually develop tumors that are morphologically identical to those described much earlier (Haaland 1911) and classified by Dunn (Dunn 1958; Sass and Dunn 1979; Cardiff et al. 2000a). Interestingly, these two genes were subsequently identified as Wnt and FGF (van Leeuwen and Nusse 1995). The complementary nature of the first two Int genes has also been shown by infecting either $\operatorname{Tg}(W n t)$ or $\operatorname{Tg}(F g f)$ mice with MMTV resulting in tumors that show viral insertional activation occurring at the $F g f$ locus in $\operatorname{Tg}(W n t)$ mice and at the Wnt locus in $\operatorname{Tg}(F g f)$ mice (Kwan et al. 1992; Shackleford et al. 1993; Lee et al. 1995).

Other types of GEM show different histological patterns that rarely mimic the spontaneous MMTV-induced tumors (Cardiff et al. 2004). Many of the mammary tumors in these mice mimic morphological features that resemble human breast cancers (Cardiff and Wellings 1999), however, to understand this histopathology we must look back some hundred years ago when Apolant published the first description of spontaneous mouse mammary tumors (Apolant 1906). Although the intervening century has brought numerous advances, the seeds for the current concepts of mammary tumor biology were planted by our predecessors. The fundamental principles articulated by these pioneers still resonate today and are now confirmed, verified and expanded using modern technology (Dunn 1945, 1958). As the mouse is now used as the test model for the biological properties of every potential human mammary oncogene, we must also recognize that the GEM (Stewart et al. 1984; Paigen 1995), is the modern equivalent to Kock's Postulates (Begemann et al. 2002).

\section{THE BEGINNING OF EXPERIMENTAL CANCER RESEARCH}

The Origins of the Laboratory Mouse

Was the Mouse Fancier the First Mouse Mammary Tumor Biologist?

The house mouse is a commensal animal, having lived with mankind for as many years as man cultivated grains. The origins of the laboratory mouse have been traced to Asian mouse fanciers (Keeler 1931; Morse 1978, 1981). (Excellent reviews of the ancient literature appear in Keller's 1931 monograph on the Origins of the Laboratory Mouse and Morse's volumes on the Origin of the Laboratory Mouse.)

The first written record appears in $1100 \mathrm{BC}$ Chinese lexicon and from the same era the Egyptian pictographs of colored mice. Meanwhile, the waltzing mouse, the parents for the first inbred strain (DBA) was described in 80 $\mathrm{BC}$ and later a manual "Breeding of Curious Varieties of The Mouse" was printed in Japan in 1787. By 1895, formal Fancy Mouse Clubs were established. These groups were creating genetically modified families through selective breeding. Later, these groups became the recorded source for mice repositories described in the early scientific literature as "from a breeder."

\section{The First Mouse Mammary Tumors}

\section{The First Description}

In science, the first to describe an observation means everything, and so it was long ago. The first scientific description of a mouse mammary tumor is credited to Crisp (1854; Dunn 1945). Crisp's first line is noteworthy because the mouse was feral, "caught in a trap." His description was written well before Virchow's cellular basis of disease and Waldeyer's description of the origin of epithelial cancers. Many scientists of the time, including Virchow, believed that all tumors arose from connective tissue rests (Rather 1978) a posit many believe today as the precursor to the modern cancer stem cell hypothesis.

By the 1890s, European scientists were using mice from "breeders" for experimental cancer research. Foremost laboratories were in France under Moreau and Germany under Ehrlich. In 1894, Moreau described a spontaneous subcutaneous tumor in the mouse as an adenocarcinoma (Dunn 1945). Livingood, of Johns Hopkins, examined mammary tumors from five mice, providing convincing 
descriptions and drawings. He illustrated pulmonary metastases and distinguished them from pulmonary adenomas (Livingood 1896). Similarly, their sources of mice were documented as "from breeders."

Spontaneous and Transplanted Tumors 1890-1911

\section{The Cross-Fertilization between Mouse Mammary Tumor Pathology and Mouse Genetics (see Fig. 1)}

As has been noted, the earliest investigators of mouse mammary tumors used mice obtained from "breeders." Although records of "families" were kept (Bashford 1911a; Haaland 1911; Murray 1911) the conceptual and technical barriers limited research. The biology of transplantation was unknown and, with the exception of the Jensen lines (Jensen 1903), all attempts at serial tumor transplantation failed until the development of inbred, genetically identical laboratory mice (Little and Tyzzer 1916; Strong 1935, 1936). However, Apolant's landmark paper provided the first clear descriptions of the epithelial origin of mouse mammary tumors (Apolant 1906). Haaland published in 1911 the first comprehensive description of mouse mammary tumors in the English language (Haaland 1911). His initial suggestions of "malignancy" was based on tumor transplantation, hypothesizing that tumors that grew upon transplantation were assumed, by definition, to be malignant. Likewise, another pathologist, Bashford even calculated that accumulative mass of all transplanted Jensen tumors exceeded the mass of the single donor (Bashford 1911a). Autochthonous transplants "took" but tumor transplants between unrelated animals rarely grew in animals and yielded no concrete evidence (Bashford 1911a; Haaland 1911; Murray 1911; Woglom 1913). However, a new paradigm of familial breast cancer in mice was being cultivated and recognized by Haaland, Bashford and Murray, Tyzzer and others during this time (Bashford 1911a; Murray 1911; Tyzzer 1909; Woglom 1913; Dunn 1945). So what were the Jensen lines and how significant were they? Jensen, working with Borrel, developed the first transplantable mouse mammary tumor line (Jensen 1903). Jensen provided "the first" mouse resource to others and is credited with establishing in no small

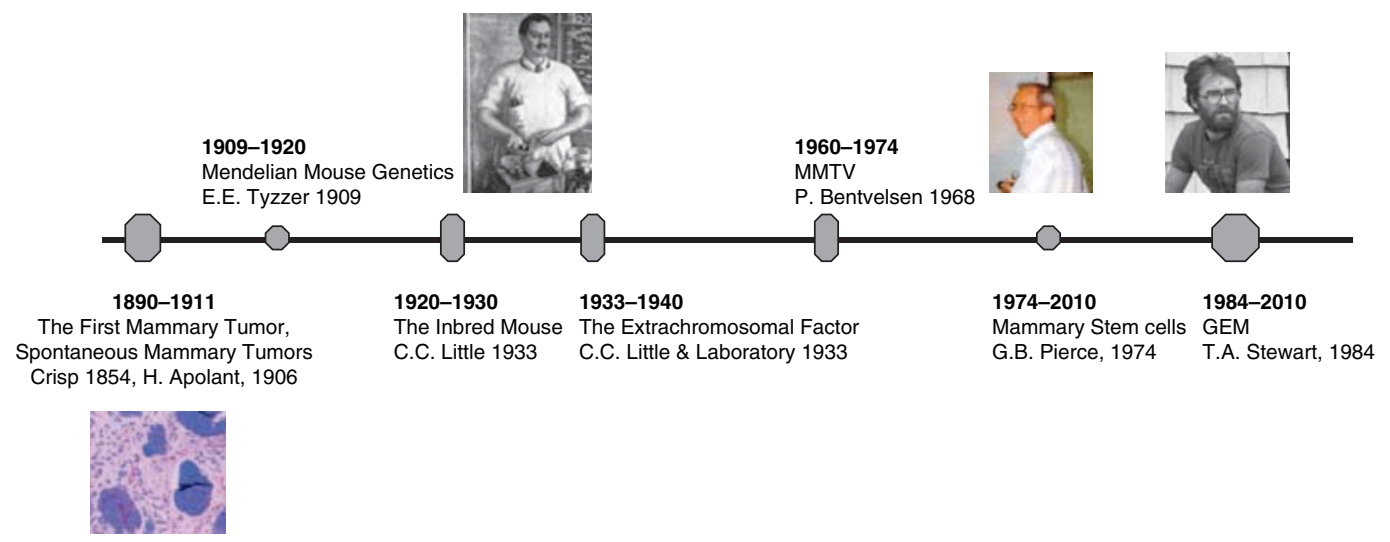

Figure 1. Historical timeline of the mouse mammary tumor biologist. A timeline of the first observation in rodent breast pathology and the development of transgenic mouse to today. (Image of CC Little courtesy of The Jackson Laboratory [http://www.jax.org/milestones/researchhighlights.htm]; image of GB Pierce reproduced from Schwartzendruber 1993 with permission from The International Journal of Developmental Biology (C) 1993; and image of TA Stewart reproduced from Hanahan et al. 2007 with permission from Cold Spring Harbor Laboratory Press (C) 2007.) 
feat, the foundation modern cancer research (Dunn 1958; Foulds 1959). However, like in most scientific arenas, controversy surrounding the origin and biology of the Jensen mouse lines remained open amongst his peers (Williams 1906). Complicating this historical concept, was Ewing who in 1919 stated that his group laid the "foundations for experimental cancer research" (Ewing 1919). Even so, it was Dunn who credits Jensen with beginning experimental cancer research by widely sharing his line (Dunn 1945, 1958; Foulds 1959), which Foulds later supported by stating that Jensen's work "...marks the beginning of modern experimental cancer research.” (Dunn 1945, 1958; Foulds 1959). She also revealed that during this time (1916) the field of "familial traits" was preempted by the application of Mendelian genetics to the mouse. Although the early experimental work was summarized by Woglom (1913) and Ewing (1919), Dr. Thelma Dunn's $(1945,1958)$ own studies involved the description and classification of murine tumors in a variety of organs including the mammary gland. Each document remains useful today because each was concise, well-organized, and clear. In particular, she eschewed the use of unfounded speculation and used simple terms.

Also to note is one of Apolant's observation parallels today's description of the EMT. Recent studies of GEM mammary tumors have shown mammary tumors undergo an epithelial-tomesenchymal transition (EMT) (Moody et al. 2005; White et al. 2001; see Fig. 1). The EMT tumor theme has been recognized in human cancers and an increasing number of citations have reflected that undifferentiated tumors often have sarcomatous characteristics and express one of several EMT-associated transcription factors (Yauch et al. 2005). These sarcomatous tumor types recorded in GEM were described, illustrated, and discussed by Apolant in 1906 (Apolant 1906), Haaland in 1911 (Haaland 1911), Bashford in 1911 (Bashford 1911a), and Woglom in 1913 (Woglom 1913), and reviewed by Dunn in 1945 and 1954 (Dunn 1945, 1958). The early investigators called these tumors carcinosarcomas. Although these spindle cell tumors were frequently associated with transplantation, they considered them an artifact of transplantation and speculated that these types of tumors could arise from a malignant stroma (Bashford 1911a). EMT tumors now can be identified by immunohistochemistry as dual staining for the intermediate filaments, cytokeratin and vimentin and loss of e-cadherin (White et al. 2001; Moody et al. 2005) and are currently the object of intense scrutiny.

\section{Mendelian Mouse Genetics: 1909-1920}

\section{The Inbred Mouse, a New Model to Study Inheritable Diseases}

During the first recession of the twentieth century, Harvard's Wm. Castles was at the forefront of the new Mendelian genetics. His graduate student, Clarence Cook Little, took on the task of discovering the genetic basis of cancer (Snell 1992). C.C. Little worked within a scientific environment that was studying familial distribution of mouse mammary tumors. Little worked with Tyzzer who is credited with experimenting with transplantation of mammary tumors (Tyzzer 1909). Part of the research team involved the best-known mouse fancier of the time Abbie Lathrop and her Granby (Massachusetts) Mouse Farm. Her career is chronicled in several reviews (Shimkin 1975; Morse 1981). Sadly, Ms. Lathrop died at 50 years of age of pernicious anemia, a controllable disease in modern times (Shimkin 1975).

Interestingly, during this time research communications between American researchers and their European counterparts were limited and often void for years at a time. Yet, the inbred mouse opened the door to the next major chapter in experimental cancer research and before the first major World War, initiated research collaborations between the Americans and Britons and Dutch with the Germans, French and later the Swedish. With a few exceptions, all subsequent studies have been largely based on the inbred laboratory mouse which is a powerful surrogate for human disease (Paigen 1995). 


\section{THE INBRED MOUSE IN MOUSE MAMMARY TUMORIGENESIS: 1920-1930}

\section{A Down Time in Mouse Mammary Tumor Biology}

The Roaring 20s are not particularly remembered for major breakthroughs. In retrospect, the 1920s was a decade of consolidation as the scientific community began to evaluate and exploit the inbred mouse (Moulton 1945). (The authors relied extensively on Rather's excellent book "The Genesis of Cancer" to provide the historical perspective of ideas in cancer research.) The scientific world was waiting for the mouse mammary tumor virus (MMTV) and the discovery of the major histocompatibility genes (MHC).

\section{THE EXTRACHROMOSOMAL FACTOR: 1933-1940 \\ The First Attempt to Isolate "the agent" that Causes Breast Cancer}

In 1933, the Staff of the Jackson Laboratory, led by C.C. Little, announced the discovery of an extra chromosomal milk factor as the cause of mammary tumors in inbred mice (Laboratory S. o. RBJM 1933). C.C. Little had been certain that the heredity of mammary cancer could be understood through mice (Crow 2002). The highly publicized 1933 paper triggered research into leading the field we now know as retrovirology, and the study protooncogenes, steroid response elements, and mammary gland specific promoters. Likewise, the discovery of MMTV has also led to extensive but futile searches for a human breast cancer virus, which remain today. Following in the footsteps of Little was John J. Bittner, who drew the assignment of exploring the nongenetic alternative, the milk factor. His research was so compelling that the agent became known as the "Bittner Virus" (Gross 1970). Bittner himself is quoted as saying that he took the study of mother's milk "because no one else wanted it." (Personal communication from Dr. Franz Halberg, a Univerisity of Minnesotta colleague and collaborator of Bittner's.)
Ironically, another of the "staff," George Snell, went on to characterize the genetics of transplantation and histocompatibility using mouse tumors (Snell 1981). Snell's studies of the genetic basis for histocompatibility was recognized in 1980 with the Nobel Prize in Medicine (Snell 1992).

\section{MMTVAND MOLECULAR ONCOLOGY: 1960-2009}

The Advent of Modern Isolation Techniques and Molecular Manipulation Experiments to Isolate the Virus that Causes Breast

\section{Cancer in Mice}

For the next twenty years following World War II, the virus was the centerpiece of mammary tumor biology. European groups collaborated with American research groups and cancer consortiums were established to share unpublished and published findings. The mechanism of cancer was still unknown and the next chapters in annals of cancer biology were not anticipated by most scientists.

The discovery and verification of the extrachromosomal "milk agent" at the Jackson Laboratory and in the Netherlands heralded a new epoch featuring the "cause" of familial breast cancer, namely the mouse mammary tumor virus (MMTV) (Laboratory S. o. RBJM 1933). The ability to study neoplastic progression using transplantation of breast tissue into inbred, syngeneic mice came after the understanding of histocompatibility governing transplant rejection (Snell 1948; Dunham and Stewart 1953; De Ome et al. 1959). The late 1970 s were sparked by the newly emerging techniques of molecular biology and molecular genetics (Shimkin 1977). Dutch investigators discovered a germ line oncogenic MMTV before the Viral Oncogene Hypothesis was developed (Bentvelzen and Daams 1969). The subsequent era focused on the ramifications of the oncogene hypothesis and unraveling the role of MMTV. Some oncogenic viruses, like avian leukosis virus, transduced a protooncogene, others, like MMTV, insert their DNA into the host genome activating oncogenes 
(Hayward et al. 1981; Nusse and Varmus 1982; Nusse et al. 1984).

Yet all these things began to initially change when Peter Bentvelsen detected, using classical genetic techniques, genetic transmission of MMTV. So potent was the observation that most investigators in the field could not comprehend his "lysogeny" concept. Peter based his hypothesis, in part, on conversations with the phage geneticist, Jacque Monod (Bentvelzen et al. 1968). They devised and published techniques to isolate and detect the endogenous virus: Cutting edge strategies not envisioned during the time. Later, their observations were subsequently confirmed with liquid phase nucleic acid hybridization.

As mammary tumor biology began to shift paradigms and molecular oncology was foreshadowed by the viral oncogene hypothesis (Huebner and Todaro 1969) and molecular biology including reverse transcriptase (Baltimore 1995), the discovery of avian and murine leukemia viruses by Temin and Baltimore in 1971 was quickly followed by confirmation of a reverse transcriptase in MMTV (Spiegelman et al. 1970). The 1971 meeting of the International Association for Breast Cancer Research held in Cherry Hill highlighted Spiegelman's announcement of the "simultaneous detection technique" for the detection of MMTV-related sequences in milk (Schlom and Spiegelman 1971; Michalides et al. 1975). Unfortunately, the specific hybridization technique proved to be nonspecific and unreliable (Roy-Burman et al. 1973).

With new technologies such as liquid phase hybridization, the molecular biology of mammary tumors began to be examined. First, like other murine retroviruses, MMTV-related sequences were encoded in the mouse genome. Intriguingly, numerous laboratories showed that the MMTV DNA was amplified in tumors and in premalignant hyperplasia (Michalides et al. 1982; Cardiff 1984). Because MMTV was not a "transforming virus" the question became whether the amplification itself induced tumors (Altrock et al. 1982).

The amplification hypothesis soon became moot with the discovery that the avian leukosis virus activated the $M y c$ cellular oncogene by insertion activation (Hayward et al. 1981). Nusse and Varmus were able to locate a common insertion site that activated a gene initially called Int1, which was subsequently found to be homologous to Wnt1 or wingless in Drosophila (Nusse and Varmus 1982; Nusse et al. 1984). Later, Dickson and Peters isolated Int2 which turned out to be Fgf 3 (Dickson et al. 1984, 1990). A third common integration site was identified by Callahan as int3 which was later determined to be Notch (Jhappan et al. 1992). One of the scientists involved in these investigations was Roel Nusse who has devoted most of his subsequent career to studies in Drosophila. Ironically, his colleague at NKI, the Drosophila geneticist Peter Bentvelzen, had been recruited to study mouse mammary tumors. Little did he know, in describing the theoretical MMTV "mam gene" in GR mice that the gene would turn out to be a homolog of a well-known Drosophila gene and a wonderful example of comparative biology (Hilgers and Bentvelzen 1981).

Although much of the virology is now only of interest to the specialist, the mouse mammary virus long terminal repeat (MMTV-LTR) is an important part of genetic engineering because it provides the most commonly used tissue specific promoter for mammary transgenesis.

Developmental Biology and Neoplastic

Progression: Mammary Stem Cells

1974-2009

\section{Serial Transplantation and the Concept of Tumor Recapitulation}

The cancer stem cell hypothesis is now so popular that journals, such as Nature, have devoted cover pages and editorial reviews to the subject (Janzen and Scadden 2006). The stem cell hypothesis was, foreshadowed by the "embryonic rest" hypothesis that Connheim and Virchow espoused in various forms (Ewing 1914; Rather 1978). Weiss, in 1933, described how vertebrate developmental structures are formed by certain cells that adapt, react, and create separate living systems (Weiss 1933). Leighton, in 1967, observed that cells within a tumor hold a structure, or "niche," separate 
A Compendium of the Mouse Mammary Tumor Biologist

and distinct from the tumor as a "biological unit" (Leighton 1967).

Following in their footsteps, the University of Colorado pathologist, Barry Pierce, identified mammary stem cells in mouse mammary tumors (Pierce and Verney 1961; Pierce 1974, 1975, 1977, 1983; Pierce et al. 1977; Sell and Pierce 1994). Pierce began his stem cell research in the late 1950s with Frank Dixon (University of Pittsburgh) with the help of Roy Stevens of the Jackson Laboratory, a colleague of C.C. Little. Pierce confirmed through EM and radioactive tritium labeling, that "long-lived label retaining cells" or undifferentiated mammary stem cell epithelium can be detected in mouse mammary tumors within distinct microenvironments (Pierce et al. 1977; see Fig. 1). This observation stands firmly in history but is rarely cited in the current stem cell literature. Recently, with the popularization of the embryonic stem cell research, the mouse has become a favorite tool for yet another branch of scientific research.

The next chapter was not exactly mammary biology, however, it is entwined in the move toward the current technology. The stem cell tumors of Roy Stevens resulted in teratocarcinomas of the testes and ovaries. Several investigators used these cells and the concepts arising from them to develop allophonic chimeras. These chimeras showed that one could develop animals with a mixture of cell types by injection of cells into embryoid bodies or the inner cells mass of blastocysts. The most interesting studies of the era belong to Martin and Evans who were able to produce progeny that could boast that their grandfather was a cancer cell (Martin 1980; Damjanov 2004). Others used chimeras to transmit lethal genes to show allelism (Eicher and Hoppe 1973) and develop human-mouse chimeras (Illmensee et al. 1978). More germane to mammary tumor biology is the infrequently cited research of Slemmer and Mintz who used allophonic chimeras to show the role of stroma in mouse mammary tumorigenesis (Mintz and Slemmer 1969; Slemmer 1974). These experiments showed the importance of the social context of neoplastic cells and were an intermediate step in thinking about genetic engineering.

\section{GENETICALLY ENGINEERED MICE (GEM): 1984-2006}

\author{
Genetically Engineered Mice are \\ the Product of Interdisciplinary \\ Research
}

\section{Genetically Engineered Mice}

Genetically modification of organisms as we know it today began with microorganisms in which a foreign DNA was inserted to a host genome. Soon, scientists were trying genetic modification of animals and specifically mice. Jaenisch was the first to report a modified mouse using SV40 DNA (Jaenisch and Mintz 1974) followed by retroviral infection of blastocysts and embryo's Hanahan has described the early history of development of tumor models and "oncomice" (Hanahan et al. 2007).

The modern era of mammary tumor research was initiated in 1984 by Stewart, Pattengale, and Leder's paper using the MMTV LTR to promote $M y c$ gene expression in the mouse mammary gland (Stewart et al. 1984). The demonstration of organ specific targeting of gene expression opened the door for using the mouse as the test bed for gene action. Since that time, the mouse has been used to test an exhaustive list of potential oncogenes and tumor suppressor genes.

The irony of the current era is that the molecular proof of the genetic origins of breast cancer that C.C. Little, Maud Slye, and others so doggedly sought in the early twentieth century has been provided. However, the proof now comes in a dramatic twist, via reverse genetic engineering (see Fig. 1).

The second lesson is neoplastic progression in GEM tumors are very similar to Haaland's recorded observations over a century ago. Although the initial descriptions recorded a "simultaneous" transformation of all mammary glands in some transgenic strains, many investigators have featured the presence of precancers in the animals with what one might consider an over-emphasis on the morphological diagnosis of ductal carcinoma in situ (DCIS)-like lesions (Cardiff et al. 2000b). However, some investigators have used the DeOme 
test-by-transplantation criteria for precancers to show both high risk (Medina 1975, 1976, 1996, 2000; Cardiff et al. 1981, 1983, 2002; Fanning et al. 1982; Pathak et al. 1987; Morris et al. 1990) and low risk hyperplastic growths (Jhappan et al. 1992; Lin et al. 1992). The Annapolis Pathology Workshop recommended that these lesions be designated mammary intraepithelial neoplasms (MIN) to distinguish them from the MMTV-induced HAN and the human DCIS (Cardiff et al. 2000a).

Recent studies of GEM mammary tumors have documented how some mammary tumors undergo an epithelial-to-mesenchymal transition (EMT) (White et al. 2001; Moody et al. 2005). The EMT tumor theme has been picked up in human cancers and an increasing number of papers have appeared showing that undifferentiated tumors often have sarcomatous characteristics and express one of several EMTassociated transcription factors (Yauch et al. 2005). The sarcomatous tumor types recorded in GEM were described, illustrated and discussed by Apolant in 1906 (Apolant 1906), Haaland (Haaland 1911) and Bashford in 1911, and Woglom in 1913, and reviewed by Dunn in 1945 and 1954 (Dunn 1945, 1958). Because these spindle cell tumors were frequently associated with transplanted tumors, some investigators considered them an artifact of transplantation. Bereft of immunohistochemistry, some early investigators speculated that these types of tumors could arise from a malignant stroma (Bashford 1911a). The earliest investigators associated breast cancer in humans and mice with inflammation and other stromal events (Haaland 1911; Ewing 1914, 1919). However, modern investigators have begun experiments that show the importance of stroma (Cunha et al. 1997; Pollard 2001; Barcellos-Hoff and Medina 2005). Now we have a growing list of stromal genes that appear to play a major role in epithelial tumorigenesis. Research by Pollard and Condeelis has riveted attention to the macrophage as a major inflammatory cell that stimulates the metastatic phenotype (Wyckoff et al. 2004). The reader will detect the continuing shadow of Virchow in these suggestions.
As recognized previously, most mouse mammary tumors metastasize to the lung. Livingood recorded pulmonary metastases in 1896 (Livingood 1896). As recorded by Borrel (1903), Haaland (1911), and then Dunn (1945), many of the metastases appear as intravascular tumor emboli. Illustrations of metastasis used by Woglom and Dunn have well defined double layers of endothelium around the emboli (Dunn 1945). The same embolic metastases occur in the current crop of GEM (Siegel et al. 2003; Oshima et al. 2004) and are considered by some investigators a "new phenomenon" (Sugino et al. 2002) and pose as an example of rediscovery of a previously described phenomenon. We should all be aware of need for continuity in institutional memory.

Modern investigators are not limited to descriptions of the phenomenon but rather have numerous GEMs that can help interrogate the mechanism(s). The "knockout" mice from which the gene in question has been removed from the genome with genetic engineering is a good example (Cardiff and Wellings 1999). Knockout mice show which genes control the type, rate of metastases, (Man et al. 2003; Siegel et al. 2003; Pollard 2004) transgene, or recurrent tumors in doxycycline-inducible models (White et al. 2001; Moody et al. 2005). With control over the molecule, the modern investigator no longer needs to speculate.

\section{Comparative Pathology of Breast Cancer}

The initial studies of mouse mammary tumors questioned whether the mouse tumors were related to human breast cancer. Livingood states that he undertook his studies in 1894 at the suggestion of Dr. Welsh, of Johns Hopkins fame, who told him that comparative pathology was a worthy pursuit (Livingood 1896). In 1911, Bashford provided an extensive rationale for studying mouse mammary tumor biology (Bashford 1911b). In 1945, Shimkin further defended the focus of NCI on mouse mammary tumorigenesis (Shimkin 1945). As recorded herein, each development in either clinical breast cancer or in basic breast cancer research has led to advances in each respected field. 
MMTV-induced tumors have always been recognized as being morphologically distinct from human breast cancers. Some authorities have speculated that the differences are because of the supposed large ductal origin of human breast cancer as compared to the acinar origin of mouse mammary tumors (Dunn 1945, 1958). However, the detailed subgross studies of Wellings and his colleagues (Wellings and Jensen 1973; Wellings et al. 1975, 1976) exploded the myth of the ductal origin of human breast cancer that originated with Foote (Foote and Stewart 1941). The commonest site of origin of breast cancer in all species now appears to be in the acinar cells. However, the details of the histology of spontaneous mouse mammary cancers have always been very different from human breast cancers. The morphology of spontaneous, MMTV-induced tumors of mice does not resemble human breast cancers. However, many of the GEM associated mammary tumors resemble human breast cancers in striking detail (Cardiff and Wellings 1999). For example, $\operatorname{Tg}(\mathrm{ErbB2} / \mathrm{neu})$ transgenics have microscopic fields that can be easily mistaken for human DCIS and $\operatorname{Tg}(s r c)$ GEM produce remarkably scirrhous tumors (Cardiff and Wellings 1999). In fact, when the NIH convened the Annapolis pathology workshop to assess the GEM models, several of the surgical pathologists without experience with mouse pathology were surprised to learn that the MMTV-induced tumors could be metastatic (Cardiff et al. 2000a). Numerous other examples can be provided and others will become apparent as the field of genetic engineering expands.

\section{ACKNOWLEDGMENTS}

This project has required the assistance of a number of very helpful people. In particular, we appreciate the assistance of Dr. Kristina Abel, University of California, Davis and Susann Kulick, Jena, Germany in translating texts. We appreciate the assistance of Nancy Nicolos, UC Davis Carlson Library and Elizabeth Evans, Hampton Univ., Reference Librarian, who magically found long mislaid, often dusty texts.
We thank our UC Davis colleagues Dr. Stephen Barthold, Dr. Alexander Borowsky, Robert Munn, and Larry Young. Dr. Murray Gardner, himself a historian, read and enthusiastically discussed the text. Dr. Daniel Medina shared his insights and materials.

\section{REFERENCES}

Altrock BW, Cardiff RD, Puma JP, Lund JK. 1982. Detection of acquired provirus sequences in mammary tumors from low-expressor, low-risk mice. J Natl Cancer Inst 68: $1037-1041$.

Apolant H. 1906. Die epithelialen geschwülste der maus. Arbeiten ad Koniglchn Inst F Expt Ther zu Frankfurt aM 1: 7-68.

Baltimore D. 1995. Discovery of the reverse transcriptase. Faseb J 9: 1660-1663.

Barcellos-Hoff MH, Medina D. 2005. New highlights on stroma-epithelial interactions in breast cancer. Breast Cancer Res 7: 33-36.

Bashford EF. 1911a. The behaviour of tumor cells during propagation. Imperial Cancer Research Fund (Great Britain), Fourth Scientific Report, pp. 131-214.

Bashford EF. 1911b. Fourth scientific report on the investigations of The Imperial Cancer Research Fund (ed. EF Bashford), pp. vii-xxi. Taylor and Francis, London, UK.

Begemann M, Fuller GN, Holland EC. 2002. Genetic modeling of glioma formation in mice. Brain Pathol 12: $117-132$.

Bentvelzen P, Daams JH. 1969. Hereditary infections with mammary tumor viruses in mice. J Natl Cancer Inst 43: 1025-1035.

Bentvelzen P, Timmermans A, Daams JH, van der Gugten A. 1968. Genetic transmission of mammary tumor inciting viruses in mice; possible implications for murine leukemia. Bibl Haematol 30: 101-103.

Bishop JM. 1993. J. Michael Bishop-Nobel lecture. In Nobel Lectures, Physiology or Medicine 1981-1990 (ed. J Linsten), pp. 530-548. World Scientific, Singapore.

Borrel A. 1903. Epithelioses infecticuses of epitheliomas. Ann de L'Inst Pasteur 17: 81-118.

Cardiff RD. 1984. Protoneoplasia: The molecular biology of murine mammary hyperplasia. Adv Cancer Res 42: $167-190$.

Cardiff RD, Wellings SR. 1999. The comparative pathology of human and mouse mammary glands. J Mammary Gland Biol Neoplasia 4: 105-122.

Cardiff RD, Anver MR, Gusterson BA, Hennighausen L, Jensen RA, Merino MJ, Rehm S, Russo J, Tavassoli FA, Wakefield LM, et al. 2000a. The mammary pathology of genetically engineered mice: The consensus report and recommendations from the Annapolis meeting. Oncogene 19: 968-988.

Cardiff RD, Bern HA, Faulkin LJ, Daniel CW, Smith GH, Young LJ, Medina D, Gardner MB, Wellings SR, Shyamala $\mathrm{G}$, et al. 2002. Contributions of mouse biology to breast cancer research. Comp Med 52: 12-31. 
R.D. Cardiff and N. Kenney

Cardiff RD, Fanning TG, Morris DW, Ashley RL, Faulkin LJ 1981. Restriction endonuclease studies of hyperplastic outgrowth lines from $\mathrm{BALB} / \mathrm{cfC} 3 \mathrm{H}$ mouse hyperplastic mammary nodules. Cancer Res 41: 3024-3029.

Cardiff RD, Moghanaki D, Jensen RA. 2000b. Genetically engineered mouse models of mammary intraepithelial neoplasia. J Mammary Gland Biol Neoplasia 5: 421-437.

Cardiff RD, Morris DW, Young LJ. 1983. Alterations of acquired mouse mammary tumor virus DNA during mammary tumorigenesis in $\mathrm{BALB} / \mathrm{cfC} 3 \mathrm{H}$ mice. $J$ Natl Cancer Inst 71: 1011-1019.

Cardiff RD, Rosner A, Hogarth MA, Galvez JJ, Borowsky AD, Gregg JP. 2004. Validation: The new challenge for pathology. Toxicol Pathol 32(Suppl. 1): 31-39.

Crisp E. 1854. Malignant tumor on the pectoral muscle of a mouse (m. Musculus). Trans Pathol Soc London 5: 348.

Crow JF. 2002. C.C. Little, cancer and inbred mice. Genetics 161: $1357-1361$

Cunha GR, Young P, Hom YK, Cooke PS, Taylor JA, Lubahn DB. 1997. Elucidation of a role for stromal steroid hormone receptors in mammary gland growth and development using tissue recombinant experiments. J Mammary Gland Biol Neoplasia 2: 393-402.

Damjanov I. 2004. From stem cells to germ cell tumors and back. Verh Dtsch Ges Pathol 88: 39-44.

De Ome KB, Faulkin LJ, Bern HA, Blair PB. 1959. A new approach to mammary tumorigenesis. Cancer 24: $1255-1258$.

Dickson C, Acland P, Smith R, Dixon M, Deed R, MacAllan D, Walther W, Fuller-Pace F, Kiefer P, Peters G. 1990. Characterization of int-2: A member of the fibroblast growth factor family. J Cell Sci Suppl 13: 87-96.

Dickson C, Smith R, Brookes S, Peters G. 1984. Tumorigenesis by mouse mammary tumor virus: Proviral activation of a cellular gene in the common integration region int- 2 . Cell 37: 529-536.

Duesberg PH, Vogt PK. 1970. Differences between the ribonucleic acids of transforming and nontransforming avian tumor viruses. Proc Natl Acad Sci U S A 67: 1673-1680.

Dunham LJ, Stewart HL. 1953. A survey of transplantable and transmissible animal tumors. J Natl Cancer Inst 13: 1299-1377.

Dunn TB. 1945. In Symposium on mammary tumors in mice (ed. FR e Moulton), pp. 13-38. American Association for the Advancement of Science, Washington, D.C.

Dunn TB. 1958. In The physiopathology of cancer (ed. F Homburger), pp. 38-84. Paul B. Hoeber, New York.

Eicher EM, Hoppe PC. 1973. Use of chimeras to transmit lethal genes in the mouse and to demonstrate allelism of the two X-linked male lethal genes jp and msd. J Exp Zool 183: 181-184.

Ewing J. 1914. Precancerous diseases and precancerous lesions, especially in the breast. Med Rec 86: 951-958.

Ewing J. 1919. Neoplastic diseases: A textbook on tumors. W.B. Saunders, Philadelphia, PA.

Fanning TG, Vassos AB, Cardiff RD. 1982. Methylation and amplification of mouse mammary tumor virus DNA in normal, premalignant, and malignant cells of GR/A mice. J Virol 41: 1007-1013.
Foote FW Jr, Stewart FW. 1941. Lobular carcinoma in situ: A rare from of mammary cancer. Am J Pathol 17: 491-496.

Foulds L. 1959. Neoplastic development. Academic, London, UK.

Gross L. 1970. Oncogenic viruses. Pergamon, Oxford, UK.

Guy CT, Webster MA, Schaller M, Parsons TJ, Cardiff RD, Muller WJ. 1992. Expression of the neu protooncogene in the mammary epithelium of transgenic mice induces metastatic disease. Proc Natl Acad Sci 89: 10578-10582.

Haaland M. 1911. In Fourth scientific report on the investigations of the Imperial Cancer Research Fund (ed. EF Bashford), pp. 1-113. Imperial Cancer Research Fund, London, UK.

Hanahan D, Wagner EF, Palmiter RD. 2007. The origins of oncomice: A history of the first transgenic mice genetically engineered to develop cancer. Genes Dev 21: 2258-2270.

Hayward WS, Neel BG, Astrin SM. 1981. Activation of a cellular onc gene by promoter insertion in ALV-induced lymphoid leukosis. Nature 290: 475-480.

Hilgers J, Bentvelzen P. 1981. In Mammary tumors in the mouse (ed. J Hilgers, M Sluyser), pp. 1-10. Elsevier, North Holland Biomedical Press, Amsterdam, The Netherlands.

Howlett AR, Bissell MJ. 1993. The influence of tissue microenvironment (stroma and extracellular matrix) on the development and function of mammary epithelium. Epithelial Cell Biol 2: 79-89.

Huebner RJ, Todaro GJ. 1969. Oncogenes of RNA tumor viruses as determinants of cancer. Proc Natl Acad Sci 64: 1087-1094.

Illmensee K, Hoppe PC, Croce CM. 1978. Chimeric mice derived from human-mouse hybrid cells. Proc Natl Acad Sci 75: 1914-1918.

Jaenisch R, Mintz B. 1974. Simian virus 40 DNA sequences in DNA of healthy adult mice derived from preimplantation blastocysts injected with viral DNA. Proc Natl Acad Sci71: $1250-1254$.

Janzen V, Scadden DT. 2006. Stem cells: Good, bad and reformable. Nature 441: 418-419.

Jensen CO. 1903. Experimentelle untersuchungren uber krebs bei mausen. Centbl F Bakt 34: 28-122.

Jhappan C, Gallahan D, Stahle C, Chu E, Smith GH, Merlino G, Callahan R. 1992. Expression of an activated Notch-related int-3 transgene interferes with cell differentiation and induces neoplastic transformation in mammary and salivary glands. Genes Dev 6: 345-355.

Keeler CE. 1931. The laboratory mouse: Its origin, heredity, and culture. Harvard University Press, Cambridge, MA.

Kwan H, Pecenka V, Tsukamoto A, Parslow TG, Guzman R, Lin TP, Muller WJ, Lee FS, Leder P, Varmus HE. 1992. Transgenes expressing the Wnt-1 and int-2 protooncogenes cooperate during mammary carcinogenesis in doubly transgenic mice. Mol Cell Biol 12: 147-154.

Laboratory S. o. RBJM. 1933. The existence of nonchromosomal influence of mammary tumors in mice. Science 78: 465-466.

Lee FS, Lane TF, Kuo A, Shackleford GM, Leder P. 1995. Insertional mutagenesis identifies a member of the Wnt gene family as a candidate oncogene in the mammary 
epithelium of int-2/Fgf-3 transgenic mice. Proc Natl Acad Sci 92: 2268-2272.

Leighton J. 1967. The spread of cancer: Pathogenesis, experimental methods, interpretations. Academic, NY.

Lin TP, Guzman RC, Osborn RC, Thordarson G, Nandi S. 1992. Role of endocrine, autocrine, and paracrine interactions in the development of mammary hyperplasia in Wnt-1 transgenic mice. Cancer Res 52: 4413-4419.

Little CC, Tyzzer EE. 1916. Further experimental studies on the inheritance of susceptibility to a transplantable carcinoma (JA) of the Japanese waltzing mouse. J Med Res 33: 393-427.

Livingood LE. 1896. Tumors in the mouse. Johns Hopkins Hospital Bull 7: 177-178.

Man AK, Young LJ, Tynan JA, Lesperance J, Egeblad M, Werb Z, Hauser CA, Muller WJ, Cardiff RD, Oshima RG. 2003. Ets2-dependent stromal regulation of mouse mammary tumors. Mol Cell Biol 23: 8614-8625.

Martin GR. 1980. Teratocarcinomas and mammalian embryogenesis. Science 209: 768-776.

Medina D. 1975. Mammary tumorigenesis in chemical carcinogen-treated mice. Cancer Chemother Rep 2: 127-181.

Medina D. 1976. Preneoplastic lesions in murine mammary cancer. Cancer Res 36: 2589-2595.

Medina D. 1996. Preneoplasia in mammary tumorigenesis. Cancer Treat Res 83: 37-69.

Medina D. 2000. The preneoplastic phenotype in murine mammary tumorigenesis. J Mammary Gland Biol Neoplasia 5: 393-407.

Michalides R, Spiegelman S, Schlom J. 1975. Biochemical characterization of putative subviral particulates from human malignant breast tumors. Cancer Res 35: 1003-1008.

Michalides R, Wagenaar E, Sluyser M. 1982. Mammary tumor virus DNA as a marker for genotypic variance within hormone-responsive GR mouse mammary tumors. Cancer Res 42: 1154-1158.

Mintz B, Slemmer G. 1969. Gene control of neoplasia. I. Genotypic mosaicism in normal and preneoplastic mammary glands of allophenic mice. J Natl Cancer Inst 43: $87-109$.

Moody SE, Perez D, Pan TC, Sarkisian CJ, Portocarrero CP, Sterner CJ, Notorfrancesco KL, Cardiff RD, Chodosh LA. 2005. The transcriptional repressor Snail promotes mammary tumor recurrence. Cancer Cell 8: 197-209.

Morris DW, Barry PA, Bradshaw HDJr, Cardiff RD. 1990. Insertion mutation of the int-1 and int-2 loci by mouse mammary tumor virus in premalignant and malignant neoplasms from the GR mouse strain. J Virol 64: 1794-1802.

Morse HC. 1978. In Proceedings of a workshop, NIH, Bethesda, Maryland, February 14-16, 1978.

Morse HC. 1981. In The mouse in biomedical research, Vol. 1 (ed. HL Forster, et al.), pp. 1-16. Academic,London, UK.

Moulton FR. 1945. In A symposium on mammary tumors in mice (ed. FR Moulton). AAAS, Washington, D.C.

Muller WJ, Sinn E, Pattengale PK, Wallace R, Leder P. 1988. Single-step induction of mammary adenocarcinoma in transgenic mice bearing the activated $c-n e u$ oncogene. Cell 54: 105-115.

Murray JA. 1911. In Imperial Cancer Research Fund, Great Britain. Fourth Scientific Report (ed. EF Bashford). Imperial Cancer Research Fund, London, UK.

Nusse R, van Ooyen A, Cox D, Fung YK, Varmus H. 1984. Mode of proviral activation of a putative mammary oncogene (int-1) on mouse chromosome 15. Nature 307: 131-136.

Nusse R, Varmus HE. 1982. Many tumors induced by the mouse mammary tumor virus contain a provirus integrated in the same region of the host genome. Cell 31: 99-109.

Oshima RG, Lesperance J, Munoz V, Hebbard L, Ranscht B, Sharan N, Muller WJ, Hauser CA, Cardiff RD. 2004. Angiogenic acceleration of Neu induced mammary tumor progression and metastasis. Cancer Res 64: $169-179$.

Paigen K. 1995. A miracle enough: The power of mice. Nat Med 1: 215-220.

Pathak VK, Strange R, Young LJ, Morris DW, Cardiff RD. 1987. Survey of int region DNA rearrangements in C3H and $\mathrm{BALB} / \mathrm{cfC} 3 \mathrm{H}$ mouse mammary tumor system. $J$ Natl Cancer Inst 78: 327-331.

Pierce GB. 1974. Neoplasms, differentiations and mutations. Am J Pathol 77: 103-118.

Pierce GB. 1975. Nonproliferating cells of tumors. Bibl Haematol 40: 271-272.

Pierce GB. 1977. Neoplastic stem cells. Adv Pathobiol 6: $141-152$.

Pierce GB. 1983. The cancer cell and its control by the embryo. Rous-Whipple Award lecture. Am J Pathol 113: 117-124.

Pierce GBJr, Verney EL. 1961. An in vitro and in vivo study of differentiation in teratocarcinomas. Cancer 14: 10171029.

Pierce GB, Nakane PK, Martinez-Hernandez A, Ward JM. 1977. Ultrastructural comparison of differentiation of stem cells of murine adenocarcinomas of colon and breast with their normal counterparts. J Natl Cancer Inst 58: $1329-1345$.

Pollard JW. 2001. Tumour-stromal interactions. Transforming growth factor- $\beta$ isoforms and hepatocyte growth factor/scatter factor in mammary gland ductal morphogenesis. Breast Cancer Res 3: 230-237.

Pollard JW. 2004. Tumour-educated macrophages promote tumour progression and metastasis. Nat Rev Cancer 4: $71-78$.

Rader KA. 2004. Making mice: Standardizing animals for American biomedical research, 1900-1955. Princeton University Press, Princeton, NJ.

Rather LJ. 1978. The genesis of cancer: A study in the history of ideas. Johns Hopkins University Press, Baltimore, MD.

Roy-Burman P, Rongey RW, Henderson BE, Gardner MB. 1973. Attempts to detect RNA tumour virus in human milk. Nat New Biol 244: 146.

Sass B, Dunn TB. 1979. Classification of mouse mammary tumors in Dunn's miscellaneous group including recently reported types. J Natl Cancer Inst 62: 1287-1293. 
R.D. Cardiff and N. Kenney

Schlom J, Spiegelman S. 1971. Simultaneous detection of reverse transcriptase and high molecular weight RNA unique to oncogenic RNA viruses. Science 174: 840-843.

Sell S, Pierce GB. 1994. Maturation arrest of stem cell differentiation is a common pathway for the cellular origin of teratocarcinomas and epithelial cancers. Lab Invest 70: $6-22$.

Shackleford GM, MacArthur CA, Kwan HC, Varmus HE. 1993. Mouse mammary tumor virus infection accelerates mammary carcinogenesis in Wnt-1 transgenic mice by insertional activation of int-2/Fgf-3 and hst/Fgf-4. Proc Natl Acad Sci 90: 740-744.

Shimkin MB. 1945. In A symposium on mammary tumors in mice (ed. FR eMoulton), pp. 1-7. AACR, Bethesda, MD.

Shimkin MB. 1975. A.E.C. Lathrop (1868-1918): Mouse Woman of Granby. Cancer Res 35: 1597-1598.

Shimkin MB. 1977. As memory serves-an informal history of the National Cancer Institute, 1937-57. J Natl Cancer Inst 59: 559-600.

Siegel PM, Shu W, Cardiff RD, Muller WJ, Massague J. 2003. Transforming growth factor $\beta$ signaling impairs Neuinduced mammary tumorigenesis while promoting pulmonary metastasis. Proc Natl Acad Sci 100: 84308435.

Sinn E, Muller W, Pattengale P, Tepler I, Wallace R, Leder P. 1987. Coexpression of MMTV/v-Ha-ras and MMTV/ c- $m y c$ genes in transgenic mice: Synergistic action of oncogenes in vivo. Cell 49: 465-475.

Slemmer G. 1974. Proceedings: Interactions of separate types of cells during normal and neoplastic mammary gland growth. J Invest Dermatol 63: 24-47.

Snell GD. 1948. Methods for the study of histocompatibility genes. J Genet 49: 87-108.

Snell GD. 1981. Studies in histocompatibility. Science 213: $172-178$.

Snell GD. 1992. Lecture for the Nobel Prize for Physiology or Medicine, 1980: Studies in histocompatibility. J Immunol 36: $513-526$.

Spiegelman S, Burny A, Das MR, Keydar J, Schlom J, Travnicek M, Watson K. Characterization of the products of DNA-directed DNA polymerases in oncogenic RNA viruses. 1970. Nature 227: 563-567.

Stehelin D, Varmus HE, Bishop JM, Vogt PK. 1976. DNA related to the transforming gene(s) of avian sarcoma viruses is present in normal avian DNA. Nature 260: 170-173.

Stewart TA, Pattengale PK, Leder P. 1984. Spontaneous mammary adenocarcinomas in transgenic mice that carry and express MTV/myc fusion genes. Cell 38: $627-637$.
Strong LC. 1935. The establishment of the $\mathrm{C}_{3} \mathrm{H}$ inbred strain of mice for the study of spontaneous carcinoma of the mammary gland. Genetics 20: 586-591.

Strong LC. 1936. Th establishment of the "A" strain of inbred mice. J Hered 27: 21-24.

Sugino T, Kusakabe T, Hoshi N, Yamaguchi T, Kawaguchi T, Goodison S, Sekimata M, Homma Y, Suzuki T. 2002. An invasion-independent pathway of blood-borne metastasis: A new murine mammary tumor model. Am J Pathol 160: $1973-1980$.

Swartzendruber DE. 1993. G. Barry Pierce-mentor. Int J Dev Biol 37: 21-24.

Tyzzer EE. 1909. A study of inheritance in mice with reference to their susceptibility to transplantable tumors. $J$ Med Res 21: 519.

van Leeuwen F, Nusse R. 1995. Oncogene activation and oncogene cooperation in MMTV-induced mouse mammary cancer. Semin Cancer Biol 6: 127-133.

Weiss P. 1933. Functional adaptation and the role of ground substances in development. Am Nat 67: 322-340.

Wellings SR, Jensen HM. 1973. On the origin and progression of ductal carcinoma in the human breast. J Natl Cancer Inst 50: 1111-1118.

Wellings SR, Jensen HM, DeVault MR. 1976. Persistent and atypical lobules in the human breast may be precancerous. Experientia 32: 1463-1465.

Wellings SR, Jensen HM, Marcum RG. 1975. An atlas of subgross pathology of the human breast with special reference to possible precancerous lesions. J Natl Cancer Inst 55: 231-273.

White DE, Cardiff RD, Dedhar S, Muller WJ. 2001. Mammary epithelial-specific expression of the integrin-linked kinase (ILK) results in the induction of mammary gland hyperplasias and tumors in transgenic mice. Oncogene 20: 7064-7072.

Williams WR. 1906. What is Jensen's tumor. Lancet 168: $1285-1286$.

Woglom WH. 1913. The study of experimental cancer research. A review. Columbia University Press, New York.

Wyckoff J, Wang W, Lin EY, Wang Y, Pixley F, Stanley ER, Graf T, Pollard JW, Segall J, Condeelis J. 2004. A paracrine loop between tumor cells and macrophages is required for tumor cell migration in mammary tumors. Cancer Res 64: 7022-7029.

Yauch RL, Januario T, Eberhard DA, Cavet G, Zhu W, Fu L, Pham TQ, Soriano R, Stinson J, Seshagiri S, et al. 2005. Epithelial versus mesenchymal phenotype determines in vitro sensitivity and predicts clinical activity of erlotinib in lung cancer patients. Clin Cancer Res 11: $8686-8698$. 


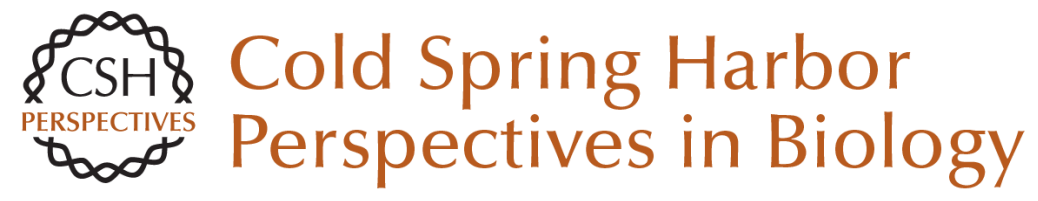

\section{A Compendium of the Mouse Mammary Tumor Biologist: From the Initial Observations in the House Mouse to the Development of Genetically Engineered Mice}

Robert D. Cardiff and Nicholas Kenney

Cold Spring Harb Perspect Biol 2011; doi: 10.1101/cshperspect.a003111 originally published online October 20, 2010

Subject Collection The Mammary Gland as an Experimental Model

On the Role of the Microenvironment in Mammary Gland Development and Cancer

Derek Radisky

On Using Functional Genetics to Understand

Breast Cancer Biology

Kornelia Polyak

On Oncogenes and Tumor Suppressor Genes in the Mammary Gland

Rushika M. Perera and Nabeel Bardeesy

On Leukocytes in Mammary Development and Cancer

Cyrus M. Ghajar

On Chromatin Remodeling in Mammary Gland

Differentiation and Breast Tumorigenesis Kornelia Polyak

On Hormone Action in the Mammary Gland J.M. Rosen

TGF- $\beta$ Biology in Mammary Development and Breast Cancer

Harold Moses and Mary Helen Barcellos-Hoff
On How Mammary Gland Reprogramming

Metalloproteinases Couple Form with Function Bonnie F. Sloane

On Molecular Mechanisms Guiding Embryonic Mammary Gland Development Gertraud W. Robinson

On Stem Cells in the Human Breast Mark A. LaBarge

On Murine Mammary Epithelial Stem Cells:

Discovery, Function, and Current Status Jeffrey M. Rosen

On In Vivo Imaging in Cancer David Piwnica-Worms

Choosing a Mouse Model: Experimental Biology in Context--The Utility and Limitations of Mouse Models of Breast Cancer Alexander D. Borowsky

Mammary Gland ECM Remodeling, Stiffness, and Mechanosignaling in Normal Development and Tumor Progression

Pepper Schedin and Patricia J. Keely

For additional articles in this collection, see http://cshperspectives.cshlp.org/cgi/collection/

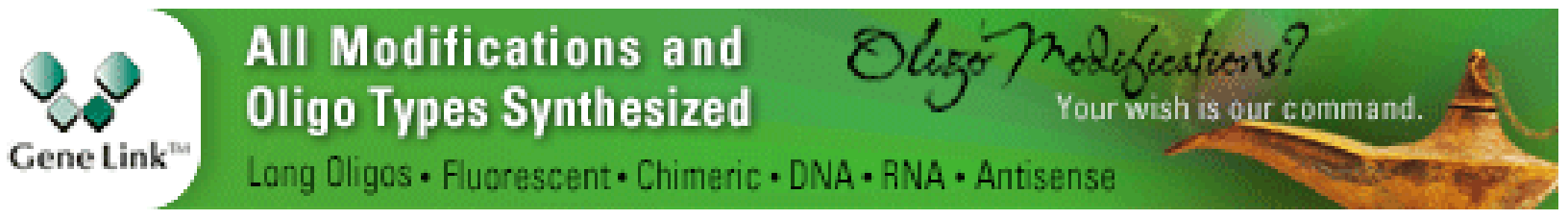


A Compendium of the Mouse Mammary Tumor Biologist: From the Initial Observations in the House Mouse to the Development of Genetically Engineered Mice

Robert D. Cardiff and Nicholas Kenney
Molecular Mechanisms Guiding Embryonic Mammary Gland Development

Pamela Cowin and John Wysolmerski

For additional articles in this collection, see http://cshperspectives.cshlp.org/cgi/collection/

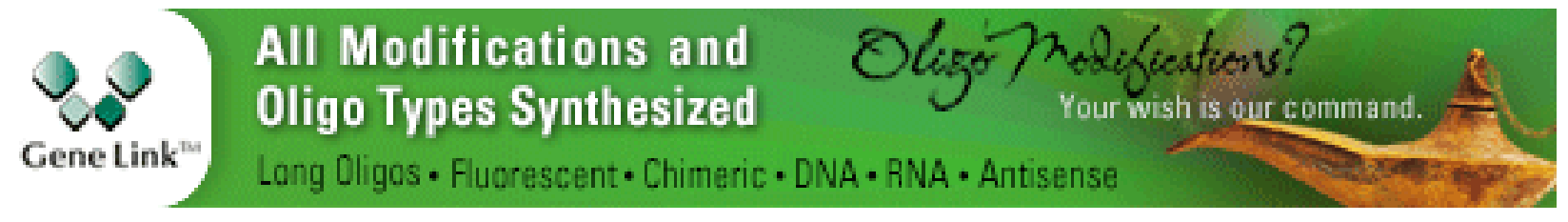

Copyright @ 2011 Cold Spring Harbor Laboratory Press; all rights reserved 